\title{
Relationship between Attribution disposition of Guardians of a Cerebral Palsy Child and Their Family Resilience
}

\author{
Soon-Gil Park \\ Jung-Sook Jun \\ Jai-Geum Han
}

\begin{abstract}
This study concerns attribution disposition and family resilience of guardians of a child with epileptic cerebral palsy and aims to examine variables affecting disability prognosis and disability acceptance degree according to whether the children have convulsion or not. Among the guardians of children at schools for students with mental retardation located in Seoul, Ansan, Cheonan, and Daegu, attribution disposition and family resilience of 88 guardians whose child had epileptic disorder and 106 guardians whose child did not have epileptic disorder, therefore 194 guardians in total were examined. Descriptive statistics, F- test, and regression analysis were conducted. The result was that attribution to fortune, attribution to efforts, and situations of crisis predicted the degree of disability acceptance. Therefore, given that epileptic cerebral palsy is a severe disability, family resilience is not acting efficiently in the adaptation process of guardians. Thus in the special education field, family support is required to improve family resilience and promote guardians' internal attribution of their children's disability for positive adaptation.
\end{abstract}

Keyword: cerebral palsy, epileptic disability, attribution disposition, family resilience

\section{Need for Research}

INTRODUCTION

Family is closely related with education services for children. Recently, in the area of special education, discussion on support for families with disabled children has been actively made and according to the need for family-centered support, the scope of interest in family support was expanded including interest in families with disabled children, support by their local community, and further enactment of family support through "Special Education for the Disabled (2007)" (Jun , 2011).

While the Individuals with Disabilities Education Act were enacted in the 1970s in the U.S., normalization of it emerged and home nurturing of disabled children was encouraged. The 'Declaration on the Rights of Disabled Persons' adopted in the 30 ${ }^{\text {th }}$ UN General Assembly in 1975 specifies that "Disabled children have the right to live with their family members or their parents and to participate in all social activities, creative activities, and recreation activities. Discrimination of the disabled regarding residence is forbidden."

142664 Daegu Bogun School., 33 50gil Sungdang-ro, Nam-gu, Daegu, Republic of Korea

262271 Doctor's Course, Dept. Special Education, Nambu Univ., 23 ChumdanJungangro,Gwangsan-gu, Gwangju, Korea 
362271 (Corresponding Author)Dept. Elementary Special Education, Nambu Univ., 23 ChumdanJungang-ro, Gwangsan-gu, Gwangju, Republic of Korea email: psoongil@nambu.ac.kr

This means that disabled children as well like non-disabled children have the right to grow in the most natural and familial environment and to this end, social support is needed for their family members to protect and educate disabled children properly. Further, as the U.S. Families of Children with Disabilities Support Act (PL 103-382) was enacted in 1994, attention to support of families with disabled children started to spread all the more (Shin, 2000; National Institute of Special Education, 2000). Like this, as of the present, the U.S. has dismantled most facilities for the disabled and is encouraging the disabled to be accepted in their local community and home, and is swiftly converting policies to the direction of actively expanding social support for their families (Jang , 2002; Bronfenbrenner, 1981). Influenced by such a developmental process of welfare for the disabled in advanced countries, Korea recently revised the Welfare of Disabled Persons Act (partially revised on April 12, 2010) and enacted Special Education Act for the Disabled; legal and institutional attention to support for families with disabled children is being paid on a national level.

Relationship between parents and children are very bilateral. Parents significantly affect their children's behaviors and at the same time children play a crucial role in forming their parents' nurturing habits. Families with disabled children undergo much burden of nurturing by taking care of their children from their youth unlike those with adult disabled persons. A lot of time spent for their family members and excessive roles and responsibilities resulting from psychological burden for a long time may result in psychological anxiety due to emotional difficulties, family conflicts, and social isolation and prejudices (Jun, 2011).

In particular, in our society with strong family consciousness, birth of a disabled child may lead to self-blame and a sense of frustration that such birth is their responsibility and the resulting chronic stress. Such tension within a family affects the entire members of the family and is circulated amid mutual relations of the family members. To compare characteristics of families with a child with epilepsy and those with an ordinary child, the former was reported to have more uncertainty about their future, lethargy, sense of frustration, helplessness, and wrath than the latter (Kim, 2007; Ellis, Upton, \& Thompson, 2000; Ferrari, Matthsews, \& Barabas, 1983). This means that families with a disabled child experience diverse psychological characteristics due to weakened integration among family members, behavioral restriction of family members, social and emotional suppression, physical tension, and financial pressure (Seidenberg, 1992; Pianta, 1994; Austin, \& McDermott, 1988; Sbarra, Rimm-Kaufman, \& Pianta, 2002).

Nonetheless, some families with disabled children may rather experience a higher sense of bond compared to those with healthy children through solidarity and cohesiveness strengthened in the process of accommodating and overcoming their disability (Kim, 2000; Singer \& Irvin, 1991; Power, 1988). In other words, families with disabled children are divided into adaptive families and non-adaptive families. Families with disabled children facing a high risk of birth of a disabled child may experience positive aspect such as more adaptation and strengthened solidarity; not all families experience breakup of family functions. That is, despite their child's disability, the families experience higher solidarity, become more intimate, and may successfully adapt to their child's disability and may perform their functions well (Singer \& Farks, 1989; Singer \& Irvin, 1991). This suggests that even though the source of tension, in other words, disability, is the same, families' adaptation forms may differ according to the characteristics of the families. 
Recently, research trend of foreign countries is focusing on the factors of what makes families better manage such situations and cope with their desires. In the past, research was mainly on family stress centered on viewpoints of weak points, but attempts to explain family adaptation centered on viewpoints of strong points and resilience concepts are increasing (McCubbin \& Patterson, 1983; Patterson \& Garwick, 1994; Lustig, 1996).

One flow of such series of previous research is on the very family resilience. Family resilience is the concept of explaining adaptive families facing a highly risky situation and has been discussed since the 1990s. Family resilience means characteristics, dimensions, and nature of families that enable families' adaptation facing a crisis situation (McCubbin et al., 1983; Hawley \& Dehaan, 1996; Walsh, 1996). Approaches to such family resilience focus on what is the mechanism to enable more successful adaptation by families facing a high risk by examining families based on families' strong points and family system theories. Therefore, family resilience considers families a dynamic unit whose resilient development is possible and emphasizes families' resources and power of elasticity to overcome such high risk. Hence, the result is the research trend on family resilience to emphasize families' relational aspects focusing on family process (Walsh, 1996; Hawley, 2000). When such concept on family resilience is applied to support of families with a cerebral palsy child, the weak point perspective of what are the problems is replaced by a viewpoint of what the current families' strong point or through which support the families' adaptation may be improved. Nevertheless, in case of Korea, research with such viewpoint is very scanty and in particular research on families with cerebral palsy children or those with epileptic cerebral palsy are almost none.

The effects of involvement in such families are not on the families only but significantly on the disabled children as well. Those families have the strongest and continuous influence on disabled children and this has been already verified in the previous studies (Cook \& Ferritor, 1985; Kelley \& Lambert, 1992; Power, 1988; Sutton, 1985). In other words, healthy families are closely and mutually related with healthy growth of their children. As for families with disabled children as well, adaptive families greatly influence disabled children's recovery of disability and social adaptation.

Epileptic disorders is chronic. Epilepsy-specific convulsion and the accompanying disabled behaviors result in social prejudice, misunderstanding, and stigma. The persons directly involved internalize negative thoughts and become very exclusive to the society or offensive and come to have psychological symptoms such as frustration and a sense of depression. According to research on parents with epilepsy children (Hoare \& Kerley, 1991), 33 percent of epilepsy children were more depressed than healthy children. Most children with epileptic disability experience abnormality in personality development or form low self-respect and negative ego concepts resulting from a sense of frustration caused by complex sociopsychological problems. As a result, their self intensity is low and they are lacking in selfconfidence, have low spiritedness, and are not smooth in social adaptation.

Thus far research mainly had a perspective of family demerits resulting from children's disability and therefore, conversion of viewpoints on how to improve adaptation of families with children with disability like cerebral palsy accompanying epileptic disability using which resources is necessary. However, in case of Korea, research examining families with disabled children with such viewpoint is very scanty and in particular, research on families nurturing children with multiple disabilities such as cerebral palsy accompanying epileptic disability is 
none. Therefore, this study intends to examine the characteristics of attribution disposition and family resilience seen with strength-based approach to guardians of cerebral palsy accompanying epileptic disability and look at relationship between family resilience with a viewpoint of merits and attribution disposition. In addition, this study will devise a basic model to support families with children having special education, form an environment to seek for application methods, and provide opportunities to create such environment.

\section{Purpose of Study}

This study aims to examine relationship between attribution dispositions of guardians who nurture children with cerebral palsy accompanying epilepsy and family resilience.

The specific purpose of this study is presented as follows.

First, this study aims to analyze attribution disposition and family resilience according to disability prognosis of guardians of children with cerebral palsy accompanying epilepsy.

Second, this study aims to analyze attribution disposition and family resilience according to the degree of disability accommodation by guardians of cerebral palsy children accompanying epilepsy.

Third, this study aims to analyze relationship between attribution disposition and family resilience according to whether the children have cerebral palsy accompanying epilepsy.

\section{Subjects}

\section{METHODOLOGY}

The subjects of this study were 88 guardians of cerebral palsy children accompanying epilepsy and 106 guardians of children with cerebral palsy not accompanying epilepsy who are attending school for mentally retarded children located in Seoul, Daegu, Inchoen, Busan, Gwangju, and Daejeon. The distribution of the respondents is shown in Table 1. 
Table 1. The Characteristics of Subjects

\begin{tabular}{|c|c|c|c|c|c|c|}
\hline \multirow[t]{2}{*}{ Variable } & \multirow[t]{2}{*}{ Item } & \multicolumn{2}{|c|}{$\begin{array}{c}\text { Accompanying Epilepsy } \\
(\mathrm{N}=88)\end{array}$} & \multicolumn{2}{|c|}{$\begin{array}{l}\text { Not Accompanying } \\
\text { Epilepsy } \\
(\mathrm{N}=106)\end{array}$} & \multirow[t]{2}{*}{$F$} \\
\hline & & $\begin{array}{l}\text { Frequency } \\
(\mathrm{N})\end{array}$ & Rate (\%) & $\begin{array}{c}\text { Frequency } \\
(\mathrm{N})\end{array}$ & Rate (\%) & \\
\hline \multirow{3}{*}{ Guardian } & Father & 6 & 6.8 & 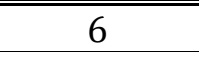 & 5.7 & \multirow{3}{*}{-.97} \\
\hline & Mother & 73 & 83.0 & 84 & 79.2 & \\
\hline & Others & 9 & 10.2 & 16 & 15.1 & \\
\hline \multirow{3}{*}{$\begin{array}{l}\text { Educational } \\
\text { Background }\end{array}$} & $\begin{array}{l}\text { Middle school } \\
\text { graduation or } \\
\text { lower level of } \\
\text { education }\end{array}$ & 5 & 5.7 & 2 & 1.9 & \multirow{3}{*}{-.62} \\
\hline & $\begin{array}{l}\text { High school } \\
\text { graduation }\end{array}$ & 36 & 40.9 & 46 & 43.4 & \\
\hline & $\begin{array}{l}\text { College } \\
\text { graduation or } \\
\text { higher level of } \\
\text { education }\end{array}$ & 47 & 53.4 & 58 & 54.7 & \\
\hline \multirow{3}{*}{$\begin{array}{l}\text { Health } \\
\text { Condition }\end{array}$} & Healthy & 40 & 45.5 & 39 & 36.8 & \multirow{3}{*}{-1.48} \\
\hline & $\begin{array}{l}\text { Moderately } \\
\text { healthy }\end{array}$ & 41 & 46.6 & 53 & 50.0 & \\
\hline & Not Healthy & 7 & 8.0 & 14 & 13.2 & \\
\hline \multirow{4}{*}{$\begin{array}{l}\text { Disability } \\
\text { Prognosis }\end{array}$} & $\begin{array}{c}\text { Became } \\
\text { sufficiently good }\end{array}$ & 11 & 12.5 & 21 & 19.8 & \multirow{4}{*}{1.41} \\
\hline & Became good & 37 & 42.0 & 42 & 39.6 & \\
\hline & $\begin{array}{c}\text { The same as } \\
\text { now }\end{array}$ & 15 & 17.0 & 22 & 20.8 & \\
\hline & $\begin{array}{l}\text { May become } \\
\text { worse }\end{array}$ & 25 & 28.4 & 21 & 19.8 & \\
\hline \multirow{4}{*}{$\begin{array}{c}\text { Disability } \\
\text { Accommodation } \\
\text { Degree }\end{array}$} & $\begin{array}{l}\text { Very well } \\
\text { accepted }\end{array}$ & 23 & 26.1 & 24 & 22.6 & \multirow{4}{*}{-.58} \\
\hline & Accepted & 50 & 56.8 & 57 & 53.8 & \\
\hline & $\begin{array}{c}\text { Moderately } \\
\text { accepted }\end{array}$ & 11 & 12.5 & 23 & 21.7 & \\
\hline & Little accepted & 4 & 4.5 & 2 & 1.9 & \\
\hline \multicolumn{2}{|c|}{ Total } & 88 & 100 & 106 & 100 & \\
\hline
\end{tabular}

\section{Study Tool}

\section{Scale of Attribution Disposition}

The testing tool used to measure attribution disposition in this study was the test on attribution disposition developed by Levenson (1981) which was revised by Yu(1990) and which was again modified and complemented by the researchers. This test is composed of two sub factors of internal attribution disposition and external attribution disposition, and this test is divided in more detail into factors of capability and efforts in internal attribution disposition and factors of others and fortune in external attribution disposition. The test is composed of a total of 32 questions with eight questions in each factor. The reliability coefficient (Chronbach's alpha) of attribution disposition was 0.74 in attribution to ability, 0.78 in attribution to efforts, 0.67 in attribution to others, and 0.76 in attribution to fortune. The 
overall attribution disposition test showed a high value of 0.83 . Hereby, the overall reliability of the attribution disposition test was good.

\section{Family Resilience Scale}

\section{Family Hardiness Index}

Family hardiness index (FHI) was developed by McCubbin, McCubbin, and Thompson (1986) in order to measure hardiness and facilitate family resilience adjustment and adaptation as an intervention or buffering factor alleviating stress sources and the results of demand as resistance against stress and adaptation resource within families. The item composed of three elements of dedication, challenge, and control. In this study, 10 questions were finally utilized. Each question was composed of 4-point Likert scale. The reliability coefficient of family hardiness (Chronbach's alpha) was 0.75 .

\section{Family Cohesiveness Scale}

The cohesiveness scale utilized cohesive items only among Family Adaptability \& Cohesiveness Evaluation Scale III, (FACES- III) developed by Olson, Portner, and Lavee (1985). The cohesiveness items were composed of 10 questions and a four-point scale. The lower the score, the higher the cohesiveness. Nonetheless, for the convenience of analysis, the cohesiveness item was reconstructed; the higher the score, the higher family cohesiveness. The reliability coefficient of family cohesiveness (Chronbach's alpha) is 0.86 .

\section{Communications Scale}

As the communications scale, family problem solving communications (FPSC) was used. This scale was developed by McCubbin, MaCubbin and Thompson (1988) and aimed at assessing family communications pattern in two sectors. It is to perceive that all families have both positive and negative communication patterns. It is to adjust family stress and measure problem solving and coping sectors of the family stress adjustment and adaptation resilience model. This study was composed of confirmative communications only. The reliability coefficient of communications (Chronbach's alpha) is 0.87 .

\section{The Scale for Crisis Situations}

Family Crisis Oriented Personal Evaluation Scales (F-Copes) was developed by McCubbin et al. in 1981 in order to assess problem solving and behavioral strategies. It explains the coping sector of the family in the resilience model of adjustment and adaptation by individuals or families within the family system and, concerns methods to deal with difficulties and problems among family members. The reliability coefficient of crisis situations (Chronbach's alpha) is 0.82 .

\section{The Scale for Social Support}

In order to measure social support, the tool developed by Park(1985) was employed. This scale is composed of a total of 25 questions and consists of four sub-factors-emotional support, informational support, material support, and appraisal support. Each item is composed of 5 Likert score; the higher the score, the higher the social support. The reliability coefficient of social support (Chronbach's alpha) is 0.97 .

\section{Study Procedure}

In order to identify the distribution of study subjects for this study, schools for mentally retarded students were selected in March 2010. The subjects were nurse teachers and teachers in charge in B, D, and S schools in Daegu and 0 school in Seoul, M school in Ansan, and S school in Cheonan. 
The result of identifying the distribution of the subjects was that a considerable number of cerebral palsy students accompanied epilepsy as in the research result that 25 percent of cerebral palsy students accompanied epilepsy (Jeon, 2000; Jun, 2000). The researchers investigated previous studies of support of families with cerebral palsy accompanying epilepsy and collected data until April 2010 and the result was that there was no research on families of cerebral palsy children accompanying epilepsy. Nonetheless, this study collected data largely from previous studies on family adaptation of parents with a child with multiple disabilities accompanying cerebral palsy and children with epilepsy and on family resilience and attribution disposition of children with chronic disability like cerebral palsy.

Based on the data collected until April 2010, attribution disposition test of May 2010 and family resilience test used in a study by Lee (2004) were revised, complemented and restructured to be suitable for this study. For the restructuralization of the test tools, advice from three experts including a special education teacher was obtained. This tool was made into questionnaires that were sent to three special education schools located in Daegu and special education schools located in Seoul, Ansan, and Cheonan in June 2010. At the time of sending the questionnaires, phone interviews with each school's vice principal, teaching director director, and relevant teachers were conducted on the need for this study and how to fill in the questionnaire. $\quad$ Yang Ten questionnaires to general cerebral palsy subjects and subjects with cerebral palsy accompanying epilepsy in the kindergarten process, the elementary process, and middle and high school process were distributed. The questionnaires distributed to each school in June 2010 were sent to each home by a responsible teacher of each school via class teachers and collected over one month until July. A total of 250 questionnaires were distributed and 200 questionnaires were collected with a high collection rate at 80 percent.

The collected questionnaires were coded during the vacation of August 2010. Excluding six questionnaires with insincere responses, 194 questionnaires were coded. According to the result of coding, the number of general cerebral palsy children's guardians was 106 and that of guardians of children with cerebral palsy accompanying epilepsy was 88.

\begin{abstract}
ANALYSIS
The data of this study was analyzed using SPSS 12.0 and each analysis method is as follows. First, in order to verify the reliability of the measurement tool, Cronbach's alpha coefficient was analyzed. Second, in order to look at the subjects' general background, descriptive statistics was used and in order to examine overall response results on major variables, means and standard deviation were calculated. Third, in order to examine whether measured variables differed according to the characteristics of general background, F test was performed. Forth, in order to examine predictive variables of attribution and family resilience affecting disability prognosis and disability accommodation degree, multiple regression analysis was carried out.
\end{abstract}

\title{
RESULTS
}

This study was conducted in order to examine relationship between attribution disposition and family resilience of guardians who are nurturing children with cerebral palsy accompanying epilepsy and the result of statistical verification according to study purpose is presented as follows. 
Park, S., \& Jun, J., \& Han, J. (2017). Relationship between Attribution disposition of Guardians of a Cerebral Palsy Child and Their Family Resilience . Advances in Social Sciences Research Journal, 4(8) 99-118.

\section{Analysis of attribution disposition and family resilience regarding disability prognosis} Analysis of Attribution Disposition According to Disability Prognosis

Table 2 shows the result of analyzing attribution disposition according to disability prognosis of children who are accompanying epilepsy and those who are not.

Table 2. Attribution Average and Standard Deviation According to Disability Prognosis of Children Who Are Accompanying Epilepsy and Those Who Are Not

\begin{tabular}{|c|c|c|c|c|c|c|c|c|c|c|c|}
\hline \multirow{2}{*}{ Variable } & \multirow{2}{*}{ Item } & \multicolumn{5}{|c|}{$\begin{array}{l}\text { The group whose children } \\
\text { accompanying epilepsy }\end{array}$} & \multicolumn{5}{|c|}{$\begin{array}{l}\text { The group whose children not } \\
\text { accompanying epilepsy }\end{array}$} \\
\hline & & $\mathrm{N}$ & M & SD & $\mathrm{F}$ & Bonferroni & $\mathrm{N}$ & M & $\mathrm{SD}$ & $\mathrm{F}$ & Bonferroni \\
\hline \multirow{5}{*}{$\begin{array}{l}\text { Attribution } \\
\text { to ability }\end{array}$} & $\begin{array}{l}\text { became } \\
\text { sufficiently } \\
\text { good }\end{array}$ & 11 & 3.84 & .93 & \multirow{5}{*}{\multicolumn{2}{|c|}{.22}} & 21 & 4.10 & .59 & \multirow{5}{*}{$2.99 *$} & \\
\hline & $\begin{array}{l}\text { became } \\
\text { good }\end{array}$ & 37 & 3.72 & .40 & & & 42 & 3.88 & .49 & & \\
\hline & $\begin{array}{l}\text { the same } \\
\text { as now }\end{array}$ & 15 & 3.82 & .52 & & & 22 & 3.70 & .47 & & \\
\hline & $\begin{array}{l}\text { became } \\
\text { worse }\end{array}$ & 25 & 3.78 & .55 & & & 21 & 3.73 & .40 & & \\
\hline & Total & 88 & 3.77 & .54 & & & 106 & 3.86 & .51 & & \\
\hline \multirow{5}{*}{$\begin{array}{l}\text { Attribution } \\
\text { to efforts }\end{array}$} & $\begin{array}{l}\text { became } \\
\text { sufficiently } \\
\text { good a }\end{array}$ & 11 & 4.31 & .64 & \multirow{5}{*}{\multicolumn{2}{|c|}{1.60}} & 21 & 4.40 & .52 & \multirow{5}{*}{$5.11^{* *}$} & \\
\hline & $\begin{array}{l}\text { became } \\
\text { good }\end{array}$ & 37 & 3.98 & .43 & & & 42 & 4.17 & .41 & & $a>c^{*}$ \\
\hline & $\begin{array}{l}\text { the same } \\
\text { as now c }\end{array}$ & 15 & 3.94 & .64 & & & 22 & 4.00 & .62 & & \\
\hline & $\begin{array}{l}\text { became } \\
\text { worse d }\end{array}$ & 25 & 3.90 & .54 & & & 21 & 3.86 & .40 & & \\
\hline & Total & 88 & 3.99 & .54 & & & 106 & 4.12 & .51 & & \\
\hline \multirow{5}{*}{$\begin{array}{l}\text { Attributior } \\
\text { to others }\end{array}$} & $\begin{array}{l}\text { became } \\
\text { sufficiently } \\
\text { good }\end{array}$ & 11 & 3.17 & .50 & \multirow{5}{*}{\multicolumn{2}{|c|}{.45}} & 21 & 2.94 & .51 & \multirow{5}{*}{$3.58^{*}$} & \\
\hline & $\begin{array}{l}\text { locame } \\
\text { good }\end{array}$ & 37 & 3.07 & .57 & & & 42 & 3.24 & .53 & & \\
\hline & $\begin{array}{l}\text { the same } \\
\text { as now }\end{array}$ & 15 & 3.25 & .45 & & & 22 & 2.93 & .50 & & \\
\hline & $\begin{array}{l}\text { became } \\
\text { worse }\end{array}$ & 25 & 3.20 & .62 & & & 21 & 3.32 & .56 & & \\
\hline & Total & 88 & 3.15 & .56 & & & 106 & 3.13 & .54 & & \\
\hline \multirow{5}{*}{$\begin{array}{l}\text { Attributior } \\
\text { to fortune }\end{array}$} & $\begin{array}{l}\text { became } \\
\text { sufficiently } \\
\text { good }\end{array}$ & 11 & 2.63 & .90 & \multirow{5}{*}{\multicolumn{2}{|c|}{$2.60^{*}$}} & 21 & 2.91 & .67 & \multirow{5}{*}{1.28} & \\
\hline & $\begin{array}{l}\text { became } \\
\text { good }\end{array}$ & 37 & 2.97 & .90 & & & 42 & 3.11 & .50 & & \\
\hline & $\begin{array}{l}\text { the same } \\
\text { as now }\end{array}$ & 15 & 3.16 & .50 & & & 22 & 3.06 & .58 & & \\
\hline & $\begin{array}{l}\text { became } \\
\text { worse }\end{array}$ & 25 & 3.19 & .49 & & & 21 & 3.24 & .51 & & \\
\hline & Total & 88 & 3.02 & .62 & & & 106 & 3.09 & .56 & & \\
\hline
\end{tabular}


According to the result of analyzing attribution disposition in accordance with disability prognosis of children who accompany epilepsy and those who do not, attribution to fortune of the groups with epilepsy significantly differed $(\mathrm{F}=2.60, \mathrm{p}<.05)$. In other words, when guardians who think their children's disability prognosis grows worse have a tendency to attribute the results of their behaviors to fortune. In attribution to ability, the disposition of attribution to ability was high in those who thought their child's health condition became sufficiently good $(M=3.84)$ and in attribution to effort as well, the disposition of attribution was high in those who thought their child's health condition became sufficiently good ( $M=4.31)$. Meanwhile, in attribution to others, the disposition of attribution to others was high in those who thought their child's health condition was the same as now $(\mathrm{M}=3.25)$. Nonetheless, there was no statistically significant difference. According to the result of analyzing attribution disposition in accordance with disability prognosis of children who accompany epilepsy and who do not, the attribution to ability of the groups not accompanying epilepsy significantly differed $(\mathrm{F}=2.99$, $\mathrm{p}<.05)$. In other words, when guardians think their children's disability prognosis becomes good, they tend to attribution the results of their behaviors to their ability.

In attribution to effort as well, there were differences between groups not accompanying epilepsy $(\mathrm{F}=5.11, \mathrm{p}<.01)$. In other words, the score of the disability prognosis was higher in the group who thought their child's health condition became sufficiently good $(M=4.40)$ than the group who thought their child's health condition was the same as now $(M=4.00)$ and it was higher in the group who thought their child's health condition became sufficiently good $(M=4.40)$ than in the group who thought their child's health condition became worse $(M=3.86)$. Therefore, guardians who thought their children's disability prognosis became good tended to attribute the results of their behaviors to their own effort. In attribution to others as well, there was difference among groups whose children did not accompany epilepsy $(\mathrm{F}=3.58, \mathrm{p}<.05)$. Therefore, guardians who think their children's disability prognosis became good have a tendency of the results of their behaviors to be controlled by others. Regarding attribution to fortune, the disposition of attribution to fortune was high in those who thought their children's prognosis became worse $(M=3.24)$. There was no statistically significant difference, though.

\section{Analysis of Family Resilience According to Disability Prognosis}

Table 3 shows the result of analyzing family resilience according to the disability prognosis of children accompanying and not accompanying epilepsy. 
Table 3-2. The Means and Standard Deviation of Family Resilience According to the Disability Prognosis of Children Accompanying Epilepsy and Not Accompanying Epilepsy

\begin{tabular}{|c|c|c|c|c|c|c|c|c|c|c|c|}
\hline \multirow{2}{*}{ Variable } & \multirow{2}{*}{ Item } & \multicolumn{5}{|c|}{$\begin{array}{l}\text { The group whose children } \\
\text { accompanying epilepsy }\end{array}$} & \multicolumn{5}{|c|}{$\begin{array}{l}\text { The group whose children not } \\
\text { accompanying epilepsy }\end{array}$} \\
\hline & & $\mathrm{N}$ & M & $\mathrm{SD}$ & $\mathrm{F}$ & Bonferroni & $\mathrm{N}$ & M & $\mathrm{SD}$ & $\mathrm{F}$ & Bonferroni \\
\hline \multirow{5}{*}{ Hardiness } & $\begin{array}{l}\text { became } \\
\text { sufficiently } \\
\text { good }\end{array}$ & 11 & 3.75 & .47 & \multirow{5}{*}{2.01} & & 21 & 3.59 & .46 & \multirow{5}{*}{1.68} & \\
\hline & became good & 37 & 3.89 & .39 & & & 42 & 3.54 & .31 & & \\
\hline & $\begin{array}{l}\text { the same as } \\
\text { now }\end{array}$ & 15 & 3.37 & .40 & & & 22 & 3.45 & .41 & & \\
\hline & $\begin{array}{l}\text { became } \\
\text { worse }\end{array}$ & 25 & 3.55 & .38 & & & 21 & 3.35 & .39 & & \\
\hline & Total & 88 & 3.52 & .41 & & & 106 & 3.50 & .39 & & \\
\hline \multirow{5}{*}{ Cohesiveness } & $\begin{array}{l}\text { became } \\
\text { sufficiently } \\
\text { good }\end{array}$ & 11 & 4.19 & .72 & \multirow{5}{*}{1.13} & & 21 & 3.82 & .65 & \multirow{5}{*}{.33} & \\
\hline & became good & 37 & 3.87 & .61 & & & 42 & 3.90 & .51 & & \\
\hline & $\begin{array}{l}\text { the same as } \\
\text { now }\end{array}$ & 15 & 3.76 & .61 & & & 22 & 3.75 & .63 & & \\
\hline & $\begin{array}{l}\text { became } \\
\text { worse }\end{array}$ & 25 & 3.94 & .59 & & & 21 & 3.81 & .69 & & \\
\hline & Total & 88 & 3.91 & .62 & & & 106 & 3.84 & .59 & & \\
\hline \multirow{5}{*}{ Communication } & $\begin{array}{l}\text { became } \\
\text { sufficiently } \\
\text { good }\end{array}$ & 11 & 4.06 & .87 & & & 21 & 3.79 & .81 & \multirow{5}{*}{.68} & \\
\hline & became good & 37 & 3.74 & .74 & & & 42 & 4.03 & .64 & & \\
\hline & $\begin{array}{l}\text { sthe same as } \\
\text { now }\end{array}$ & 15 & 3.73 & .67 & .59 & & 22 & 3.83 & .81 & & \\
\hline & $\begin{array}{l}\text { became } \\
\text { worse }\end{array}$ & 25 & 3.84 & .75 & & & 21 & 3.97 & .70 & & \\
\hline & Total & 88 & 3.81 & .74 & & & 106 & 3.93 & .72 & & \\
\hline \multirow{5}{*}{ Crisis situation } & $\begin{array}{l}\text { Became } \\
\text { sufficiently } \\
\text { gooda }\end{array}$ & 11 & 4.15 & .51 & & & 21 & 4.05 & .54 & \multirow{5}{*}{$3.16^{*}$} & \\
\hline & $\begin{array}{l}\text { became } \\
\text { goodb }\end{array}$ & 37 & 3.62 & .47 & & $a>b^{*}$ & 42 & 3.70 & .52 & & \\
\hline & $\begin{array}{l}\text { the same as } \\
\text { nowc }\end{array}$ & 15 & 3.54 & .57 & $3.48^{*}$ & $a>c^{*}$ & 22 & 3.60 & .48 & & $a>c^{*}$ \\
\hline & $\begin{array}{l}\text { became } \\
\text { worse }\end{array}$ & 25 & 3.73 & .57 & & & 21 & 3.64 & .61 & & \\
\hline & Total & 88 & 3.71 & .54 & & & 106 & 3.74 & .55 & & \\
\hline \multirow{5}{*}{ Social support } & $\begin{array}{l}\text { became } \\
\text { sufficiently } \\
\text { good }\end{array}$ & 11 & 4.10 & .85 & \multirow{5}{*}{1.41} & & 21 & 4.08 & .73 & \multirow{5}{*}{1.19} & \\
\hline & became good & 37 & 3.71 & .75 & & & 42 & 4.04 & .61 & & \\
\hline & $\begin{array}{l}\text { the same as } \\
\text { now }\end{array}$ & 15 & 3.53 & .60 & & & 22 & 3.79 & .70 & & \\
\hline & $\begin{array}{l}\text { became } \\
\text { worse }\end{array}$ & 25 & 3.81 & .68 & & & 21 & 3.84 & .68 & & \\
\hline & Total & 88 & 3.76 & .73 & & & 106 & 3.96 & .67 & & \\
\hline
\end{tabular}


Table 3 shows that according to the result of analyzing family resilience in accordance with disability prognosis of children accompanying epilepsy and those not accompanying it, there was significant difference among the groups accompanying epilepsy $(\mathrm{F}=3.48, \mathrm{p}<.05)$. In other words, the group that responded that their children's condition became sufficiently good $(M=4.15)$ obtained a higher score than the group that responded that their children's condition became good $(M=3.62)$, and the group that responded that their children's condition became sufficiently good $(M=4.15)$ obtained a higher score than the group that responded that their children's condition was the same as now $(M=3.54)$. Therefore, guardians who think the disability prognosis of their child with cerebral palsy accompanying epilepsy will become good tend to have a higher ability to cope with crisis situations. In hardiness, the group that responded that their child's health condition became good had higher hardiness $(\mathrm{M}=3.89)$ and in cohesiveness, the group that responded that their child's health condition became sufficiently good had higher cohesiveness $(M=4.19)$. In communications as well, the group that responded that their child's health condition became sufficiently good had higher communications $(\mathrm{M}=4.06)$ and in social support, the group that responded their child's health condition became sufficiently good had higher social support $(M=4.11)$. Nonetheless, the difference was not statistically significantly different.

According to the result of analyzing family resilience according to disability prognosis of children who accompanied epilepsy and did not accompany epilepsy, there was significant difference in crisis situations among the groups not accompanying epilepsy $(F=3.16, p<.05)$. In other words, the group that answered that their child's health condition became sufficiently good $(M=4.05)$ obtained a higher score than the group that answered that their child's health condition was the same as now $(\mathrm{M}=3.60)$. Therefore, guardians who think the disability prognosis of children not accompanying epilepsy tend to have high ability to cope with crisis situations. In hardiness, the group that responded that their child's health condition became sufficiently good tended to have high hardiness $(\mathrm{M}=3.59)$ and in cohesiveness, the group that responded that their child's health condition became good tended to have high cohesiveness $(M=3.90)$. In communication, the group that responded that their child's health condition became good tended to have high communications $(M=4.03)$. Meanwhile, in social support, the group that answered their child's health condition became sufficiently good tended to have high social support $(M=4.08)$. Nonetheless, there was no statistically significant difference between the groups.

\section{Attribution Disposition and Family Resilience According to the Degree of Disability Acceptance}

This study comparatively analyzed attribution disposition and family resilience according to disability acceptance degree of guardians nurturing children with cerebral palsy accompanying epilepsy.

\section{Analysis of Attribution Disposition According to Disability Acceptance Degree}

Table 4 shows the result of analyzing attribution disposition according to the degree of disability acceptance in children with cerebral palsy accompanying and not accompanying epilepsy 
Table 4. Attribution Means and Standard Deviation According to Disability Acceptance Degree in Cerebral Palsy Children Accompanying and Not Accompanying Disability

\begin{tabular}{|c|c|c|c|c|c|c|c|c|c|c|c|}
\hline \multirow{2}{*}{ Variable } & \multirow{2}{*}{ Item } & \multicolumn{5}{|c|}{$\begin{array}{l}\text { Group whose children } \\
\text { accompanying epilepsy }\end{array}$} & \multicolumn{5}{|c|}{$\begin{array}{l}\text { Group whose children not } \\
\text { accompanying epilepsy }\end{array}$} \\
\hline & & $\mathrm{N}$ & M & SD & $\mathrm{F}$ & Bonferroni & $\mathrm{N}$ & M & SD & $\mathrm{F}$ & Bonferroni \\
\hline & $\begin{array}{l}\text { Very well } \\
\text { accepted }\end{array}$ & 23 & 3.99 & .74 & \multirow{5}{*}{2.56} & & 24 & 4.05 & .54 & \multirow{5}{*}{1.93} & \\
\hline & Accepted & 49 & 3.74 & .44 & & & 57 & 3.77 & .50 & & \\
\hline \multirow[t]{5}{*}{$\begin{array}{l}\text { Attribution } \\
\text { to ability }\end{array}$} & $\begin{array}{l}\mathrm{n}_{\text {Moderately }} \\
\text { accepted }\end{array}$ & 12 & 3.50 & .41 & & & 23 & 3.84 & .48 & & \\
\hline & $\begin{array}{l}\text { Little } \\
\text { accepted }\end{array}$ & 4 & 3.59 & .12 & & & 2 & 4.13 & .18 & & \\
\hline & Total & 88 & 3.77 & .54 & & & 106 & 3.86 & .51 & & \\
\hline & $\begin{array}{l}\text { Very well } \\
\text { accepted a }\end{array}$ & 23 & 4.29 & .54 & \multirow{5}{*}{$4.90^{* *}$} & & 24 & 4.29 & .47 & \multirow{5}{*}{1.32} & \\
\hline & Accepted b & 49 & 3.94 & .48 & & & 57 & 4.09 & .47 & & \\
\hline \multirow[t]{3}{*}{$\begin{array}{l}\text { Attribution } \\
\text { to efforts }\end{array}$} & $\begin{array}{l}{ }^{n} \text { Moderately } \\
\text { accepted c }\end{array}$ & 12 & 3.66 & .56 & & $\mathrm{a}>\mathrm{c}^{* *}$ & 23 & 4.01 & .64 & & \\
\hline & $\begin{array}{l}\text { Little } \\
\text { accepted }\end{array}$ & 4 & 3.78 & .43 & & & 2 & 4.00 & .18 & & \\
\hline & Total & 88 & 3.99 & .54 & & & 106 & 4.12 & .51 & & \\
\hline \multirow{5}{*}{$\begin{array}{l}\text { Attribution } \\
\text { to others }\end{array}$} & $\begin{array}{l}\text { Very well } \\
\text { accepted }\end{array}$ & 23 & 3.21 & .64 & & & 24 & 2.93 & .45 & \multirow{5}{*}{1.54} & \\
\hline & Accepted & 49 & 3.10 & .54 & & & 57 & 3.20 & .56 & & \\
\hline & $\begin{array}{l}{ }^{n} \text { Moderately } \\
\text { accepted }\end{array}$ & 12 & 3.25 & .51 & .37 & & 23 & 3.15 & .58 & & \\
\hline & $\begin{array}{l}\text { Little } \\
\text { accepted }\end{array}$ & 4 & 3.22 & .41 & & & 2 & 3.38 & .35 & & \\
\hline & Total & 88 & 3.15 & .56 & & & 106 & 3.13 & .54 & & \\
\hline \multirow{5}{*}{$\begin{array}{l}\text { Attributior } \\
\text { to fortune }\end{array}$} & $\begin{array}{l}\text { Very well } \\
\text { accepted }\end{array}$ & 23 & 2.93 & .65 & & & 24 & 2.89 & .61 & \multirow{5}{*}{1.41} & \\
\hline & Accepted & 49 & 3.02 & .62 & & & 57 & 3.14 & .52 & & \\
\hline & $\begin{array}{l}\mathrm{n}_{\text {Moderately }} \\
\text { accepted }\end{array}$ & 12 & 3.22 & .52 & .57 & & 23 & 3.16 & .59 & & \\
\hline & $\begin{array}{l}\text { Little } \\
\text { accepted }\end{array}$ & 4 & 3.03 & .75 & & & 2 & 3.06 & .27 & & \\
\hline & Total & 88 & 3.02 & .62 & & & 106 & 3.09 & .56 & & \\
\hline
\end{tabular}

Table 4 shows the result of analyzing attribution disposition according to the degree of disability acceptance in those with children accompanying and not accompanying epilepsy, and attribution to efforts of the groups with a child accompanying epilepsy showed significant difference among the groups $(\mathrm{F}=4.90, \mathrm{p}<.01)$. The score of those who responded that they very well accepted their children's disability $(M=4.29)$ was higher than that of those who responded that they accepted their children's disability $(M=3.94)$, and the score of those who responded that they very well accepted their children's disability $(M=4.29)$ was higher than that of those who responded that they moderately accepted their children's disability $(M=3.66)$. Therefore, the better they accepted their children's disability, the stronger tendency they had to attribute the results of their behaviors to their own efforts. In attribution to ability, those who very well 
accepted their child's disability had higher attribution disposition ( $M=3.99)$. In attribution to others, those who answered that they moderately accepted their child's disability had high disposition of attribution to others $(M=3.25)$ and in attribution to fortune, those who answered that they moderately accepted their child's disability had high disposition of attribution to fortune ( $\mathrm{M}=3.22)$. Nonetheless, there was not statistically significant difference.

The result of analyzing attribution disposition according to the degree of disability acceptance in children accompanying and not accompanying epilepsy was that in attribution to ability of those whose children did not accompany epilepsy, those who little accepted their child's disability had high disposition of attribution to ability $(M=4.13)$, in attribution to efforts, those who very well accepted their child's disability had high disposition of attribution to efforts $(M=4.29)$, in attribution to others, those who little accepted their child's disability had high disposition of attribution to others $(\mathrm{M}=3.3)$, and in attribution to fortune, those who moderately accepted their child's disability had high disposition of attribution to fortune $(M=3.16)$. Nonetheless, there were no statistically significant differences in all subareas.

\section{Analysis of Family Resilience According to Disability Acceptance Degree}

Table 5 shows the result of analyzing family resilience according to disability acceptance degree in parents with cerebral palsy children accompanying and not accompanying epilepsy 
Table 5. The Means and Standard Deviation of Family Resilience According to the Degree of Disability Acceptance in Parents whose Cerebral Palsy Children Are Accompanying and Not Accompanying Epilepsy

\begin{tabular}{|c|c|c|c|c|c|c|c|c|c|c|c|}
\hline \multirow{2}{*}{ Variable } & \multirow{2}{*}{ Item } & \multicolumn{5}{|c|}{$\begin{array}{l}\text { Group whose child accompanying } \\
\text { epilepsy }\end{array}$} & \multicolumn{5}{|c|}{$\begin{array}{l}\text { Group whose child not } \\
\text { accompanying epilepsy }\end{array}$} \\
\hline & & $\mathrm{N}$ & M & SD & $\mathrm{F}$ & Bonferroni & $\mathrm{N}$ & M & SD & $\mathrm{F}$ & Bonferroni \\
\hline \multirow{5}{*}{ Hardiness } & $\begin{array}{l}\text { Very well } \\
\text { accepted a }\end{array}$ & 23 & 3.59 & .43 & \multirow{5}{*}{.81} & & 24 & 3.72 & .33 & \multirow{5}{*}{$4.76^{* *}$} & \multirow{5}{*}{$a>c^{* *}$} \\
\hline & Accepted & 49 & 3.53 & .42 & & & 57 & 3.48 & .35 & & \\
\hline & $\begin{array}{l}\text { Moderately } \\
\text { accepted c }\end{array}$ & 12 & 3.41 & .26 & & & 23 & 3.32 & .43 & & \\
\hline & $\begin{array}{l}\text { Little } \\
\text { accepted }\end{array}$ & 4 & 3.33 & .56 & & & 2 & 3.35 & .21 & & \\
\hline & Total & 88 & 3.52 & .41 & & & 106 & 3.50 & .39 & & \\
\hline \multirow{5}{*}{ Cohesiveness } & $\begin{array}{l}\text { Very well } \\
\text { accepted a }\end{array}$ & 23 & 4.07 & .59 & & & 24 & 4.15 & .51 & \multirow{5}{*}{$4.00^{* *}$} & \\
\hline & Accepted & 49 & 3.90 & .69 & & & 57 & 3.82 & .56 & & \\
\hline & $\begin{array}{l}\text { Moderately } \\
\text { accepted c }\end{array}$ & 12 & 3.72 & .32 & 1.13 & & 23 & 3.58 & .67 & & $a>c^{* *}$ \\
\hline & $\begin{array}{l}\text { Little } \\
\text { accepted }\end{array}$ & 4 & 3.68 & .34 & & & 2 & 3.60 & .14 & & \\
\hline & Total & 88 & 3.91 & .62 & & & 106 & 3.84 & .59 & & \\
\hline \multirow{5}{*}{ Communications } & $\begin{array}{l}\text { Very well } \\
\text { accepted a }\end{array}$ & 23 & 4.13 & .78 & & & 24 & 4.11 & .73 & \multirow{5}{*}{$2.98^{*}$} & \\
\hline & Accepted & 49 & 3.78 & .73 & & & 57 & 4.01 & .65 & & \\
\hline & $\begin{array}{l}\text { sModerately } \\
\text { accepted c }\end{array}$ & 12 & 3.36 & .52 & $3.26^{*}$ & $a>c^{*}$ & 23 & 3.57 & .73 & & \\
\hline & $\begin{array}{l}\text { Little } \\
\text { accepted }\end{array}$ & 4 & 3.58 & .50 & & & 2 & 3.67 & 1.41 & & \\
\hline & Total & 88 & 3.81 & .74 & & & 106 & 3.93 & .72 & & \\
\hline \multirow{5}{*}{ Crisis Situation } & $\begin{array}{l}\text { Very well } \\
\text { accepted a }\end{array}$ & 23 & 4.03 & .56 & & & 24 & 4.05 & .52 & \multirow{5}{*}{$3.83^{*}$} & \multirow{5}{*}{$a>b^{*}$} \\
\hline & Accepted b & 49 & 3.63 & .55 & & $a>b^{*}$ & 57 & 3.68 & .51 & & \\
\hline & $\begin{array}{l}\text { Moderately } \\
\text { accepted c }\end{array}$ & 12 & 3.48 & .25 & $4.62^{* *}$ & $a>c^{*}$ & 23 & 3.56 & .57 & & \\
\hline & $\begin{array}{l}\text { Little } \\
\text { accepted }\end{array}$ & 4 & 3.41 & .22 & & & 2 & 3.59 & .71 & & \\
\hline & Total & 88 & 3.71 & .54 & & & 106 & 3.74 & .55 & & \\
\hline \multirow{5}{*}{ Social Support } & $\begin{array}{l}\text { Very well } \\
\text { accepted a }\end{array}$ & 23 & 4.00 & .68 & & & 24 & 4.27 & .69 & \multirow{5}{*}{$3.72^{*}$} & \multirow{5}{*}{$a>c^{*}$} \\
\hline & Accepted & 49 & 3.73 & .78 & & & 57 & 3.95 & .61 & & \\
\hline & $\begin{array}{l}\text { Moderately } \\
\text { accepted c }\end{array}$ & 12 & 3.54 & .22 & 1.73 & & 23 & 3.67 & .69 & & \\
\hline & $\begin{array}{l}\text { Little } \\
\text { accepted }\end{array}$ & 4 & 3.35 & 1.11 & & & 2 & 3.48 & .40 & & \\
\hline & Total & 88 & 3.76 & .73 & & & 106 & 3.96 & .67 & & \\
\hline
\end{tabular}


Table 5 shows the result of analyzing family resilience according to disability acceptance degree of family whose cerebral palsy child is accompanying or not accompanying epilepsy; communications significantly differed among the groups whose child was accompanying epilepsy $(\mathrm{F}=3.26, \mathrm{p}<.05)$. In other words, the group that very well accepted their child's health condition $(M=4.13)$ obtained a higher score than the group that moderately accepted it $(M=3.36)$. Therefore, the better the groups accepted disability of their child, the higher their communication levels. There was significant difference in crisis situations among the groups whose cerebral palsy child accompanied epilepsy $(\mathrm{F}=4.62, \mathrm{p}<.01)$. In other words, the group that very well accepted their child's disability obtained higher scores than the group that accepted their child's disability ( $M=3.63)$, and the group that very well accepted $(M=4.00)$ their child's disability obtained higher scores than the group that moderately accepted it $(M=3.48)$. Thus, the better the group accepted their child's disability, the higher the family resilience during crisis situations. The group that very well accepted their child's disability had high hardiness $(M=3.59)$, high cohesiveness $(M=4.07)$, and social support $(M=4.00)$. However, there was no statistically significant difference.

According to the result of analyzing family resilience in accordance with disability acceptance degree of those who have cerebral palsy children accompanying and not accompanying epilepsy, the hardiness of the groups whose child did not accompany epilepsy significantly differed $(\mathrm{F}=4.76, \mathrm{p}<.01)$. In other words, the score of the group that very well accepted their child's disability was higher than the group that moderately accepted their children's disability $(M=3.32)$. Therefore, the better a family accepts its child's disability, the higher its hardiness. Cohesiveness was significantly different among groups with a child whose cerebral palsy did not accompany epilepsy $(\mathrm{F}=4.00, \mathrm{p}<.01)$. In other words, the score of the group that very well accepted their child's disability $(M=4.15)$ was higher than that of the group that moderately accepted their child's disability $(\mathrm{M}=3.58)$.

Therefore, the better a family accepted its child's disability, the higher its cohesiveness. In the groups whose cerebral palsy child had no epilepsy, communications significantly differed $(\mathrm{F}=2.98, \mathrm{p}<.05)$. In other words, the score was higher in the groups that very well accepted their child's disability $(M=4.11)$ than the group that moderately accepted it $(M=3.57)$. Thus, the better a family accepts his child's disability, the higher its communications. In the groups whose cerebral child had no epilepsy, the crisis situations significantly differed $(\mathrm{F}=3.83, \mathrm{p}<.01)$. In other words, the score was higher in the group that very well accepted their child's disability $(M=4.05)$ than the groups that accepted their child's disability $(M=3.68)$ and moderately accepted their child's disability $(M=3.56)$. Thus, the better a family accepts its child's disability, the better its coping ability against crisis situations. In the groups that did not accompany epilepsy, social support significantly differed $(\mathrm{F}=3.72, \mathrm{p}<.05)$. In other words, the score of the group that very well accepted its child's disability $(\mathrm{M}=4.27)$ was higher than that of the group that moderately accepted its child's disability $(\mathrm{M}=3.67)$. Thus, the better a family accepts its child's disability, the higher the social support. There were statistically significant differences in all sub-areas.

\section{Relationship between Attribution Disposition of Guardians of a Child with Disability Accompanying Epilepsy The Variables of Attribution and Family Resilience Affecting Groups Whose Children with Cerebral Palsy Accompanying Epilepsy}

The results of regression analysis in order to examine the variables of attribution disposition (attribution to ability, attribution to efforts, attribution to others, attribution to fortune) and 
the variables of family resilience (hardiness, cohesiveness, communications, crisis situations, and social support) predicting disability prognosis and disability acceptance degree of guardians who nurture a child with cerebral palsy accompanying epilepsy are shown in Table 6.

Table 6. Attribution and Family Resilience Variables Affecting Groups whose cerebral palsy child has epilepsy

\begin{tabular}{llllll}
\hline Variable $\Rightarrow$ Predictive Variable & $\mathrm{B}$ & $\mathrm{B}$ & $\mathrm{t}$ & $\mathrm{R} 2$ \\
\hline $\begin{array}{l}\text { Disability } \\
\text { Prognosis }\end{array}$ & $\begin{array}{l}\text { Attribution to } \\
\text { fortune }\end{array}$ & .45 & .27 & $2.57^{*}$ & .07 \\
\hline $\begin{array}{l}\text { Disability } \\
\text { Acceptance }\end{array}$ & $\begin{array}{l}\text { Attribution to } \\
\text { efforts }\end{array}$ & -.35 & -.25 & $-2.17^{*}$ & \\
Degree & Crisis Situations & -.32 & -.23 & $-2.01^{*}$ & .17 \\
\hline
\end{tabular}

* p<.05 Disability Prognosis: F(1,86)=6.58, p<.05, Disability Acceptance Degree: $F(2,85)=8.42, \mathrm{p}<.001$

Table 6 shows the predictive variables of attribution disposition and family resilience in guardians of a child with cerebral palsy accompanying epilepsy. The predictive variable for disability prognosis was attribution to fortune $(\beta=.27, \mathrm{p}<.05)$; this variable explained $7 \%$ of the disability prognosis variance $(F(1,86)=6.58, p<.05)$. Hence, the variable affecting disability prognosis of guardians with a child with cerebral palsy accompanying epilepsy is attribution to fortune.

The predictive variables of disability acceptance degree were attribution to efforts $(\beta=-.25$, $\mathrm{p}<.05)$ and crisis situations $(\beta=-.23, \mathrm{p}<.05)$. The variables of attribution to efforts and crisis situations may explain $17 \%$ of the disability acceptance degree variance $(F(2,85)=8.42$, $\mathrm{p}<.001$ ). Thus, the variables affecting disability acceptance degree of guardians of a child with cerebral palsy accompanying epilepsy are attribution to efforts and crisis situations.

\section{The variables of attribution and family resilience affecting groups whose children with cerebral palsy are not accompanying epilepsy}

The results of regression analysis in order to examine the variables of attribution disposition (attribution to ability, attribution to efforts, attribution to others, attribution to fortune) and the variables of family resilience (hardiness, cohesiveness, communications, crisis situations, and social support) predicting disability prognosis and disability acceptance degree of guardians who nurture a child with cerebral palsy not accompanying epilepsy are shown in Table 7.

Table 7. Attribution and Family Resilience Variables Affecting Groups whose cerebral palsy child has no epilepsy

\begin{tabular}{llllll}
\hline Variable -> Predictive Variable & $\mathrm{B}$ & $\mathrm{B}$ & $\mathrm{t}$ & $\mathrm{R} 2$ \\
\hline Disability & Attribution to & -.71 & -.35 & $-3.83^{* * *}$ & .13 \\
Prognosis & efforts & -.48 & -.26 & $-2.36^{*}$ & \\
Disability & Hardiness & .23 & $2.47^{*}$ & .19 \\
Acceptance & Attribution to others.31 & -.22 & $-2.08^{*}$ & \\
Degree & Cohesiveness & -.27 & & \\
\hline
\end{tabular}

${ }^{*} \mathrm{p}<.05,{ }^{* *} \mathrm{p}<.01,{ }^{* * *} \mathrm{p}<.001$ Disability Prognosis: $F(1,103)=14.67, p<.001$, Disability Acceptance Degree:

$F(3,101)=7.74, p<.001$ 
In Table 7 , the predictive variables of disability prognosis were attribution to efforts $(\beta=.35$, $\mathrm{p}<.001)$. This variable may explain $13 \%$ of the disability prognosis variance $(\mathrm{F}(1,103)=14.67$, $\mathrm{p}<.001)$. Hence, the variable affecting disability prognosis of guardians with a child with cerebral palsy not accompanying epilepsy is attribution to efforts.

The predictive variables of disability acceptance degree were hardiness $(\beta=-.26, p<.05)$, attribution to others $(\beta=23, p<.05)$, and cohesiveness $(\beta=-.22, p<.05)$. These variables may explain $19 \%$ of disability acceptance degree variance $(F(3,101)=7.74, p<.001)$. Therefore, the variables that affect disability acceptance degree of guardians with a child with cerebral palsy not accompanying epilepsy include hardiness, attribution to others, and cohesiveness.

\section{DISCUSSION AND CONCLUSION}

This study analyzed attribution disposition and family resilience of guardians who had a child with cerebral palsy accompanying epileptic disability and examined predictive variables affecting the guardians' disability prognosis and disability acceptance degree.

First, in guardians of a child with cerebral palsy accompanying epilepsy, the worse disability prognosis of their child, the more their attribution to their fortune, and the more positively they thought about disability prognosis, the higher their ability to cope with crisis situations. This result supports a previous study (Ward \& Bower, 1978) that parents of a child with cerebral palsy accompanying epilepsy well respond.

Second, in guardians of a child with cerebral palsy accompanying epilepsy, the better they accepted their child's disability, the more their attribution to their efforts and the higher their ability to cope with crisis situations. The better the groups with a child who had a cerebral palsy accompanying epilepsy accepted their child's disability, the higher their ability to cope with a crisis situation and the better their communications; this was consistent with the result of previous research (Austin \& McDermott, 1988; Lee, 2004) that when parents had positive attitudes toward the given situation, they well responded, but inconsistent with the result of a study by Northouse (1984) on family with a cancer patient that the effect of a disease on family adaptation was low through the stage and severity of a disease by a family's difficulty with communication that may deal with anxiety about death and fear about disease prognosis. Nonetheless, the result of the present study that the overall sub-variables of family resilience were higher in the groups with a child not accompanying epilepsy than in the groups with a child accompanying epilepsy is inconsistent with the result of a previous study (Kim, 2000) that the function of the family with a child who had epilepsy was not low and the stress level of mothers with an epilepsy child was not high. What such result suggests is that families with a child accompanying epilepsy are overall less elastic than those with a child not accompanying epilepsy. Third, the disability prognosis of guardians with a cerebral palsy child accompanying epilepsy affected attribution to fortune, and their disability acceptance degree influenced attribution to efforts and crisis situations in family elasticity. This is consistent with the result of a previous study (Lee, 2004) that explanatory power of elasticity was lower than explanatory power of stress. Guardians with a child who had cerebral palsy accompanying epilepsy attributed disability prognosis to fortune due to their child's accompaniment of epilepsy, while their disability acceptance degree was considered to be resolved if efforts were made and family members well overcame difficulties and problems.

This study compared groups with a child who had cerebral palsy accompanying epilepsy and groups with a child who had cerebral palsy not accompanying epilepsy and the sub-variables 
of family resilience were lower in the groups with a child with cerebral palsy accompanying epilepsy. This may be interpreted as family resilience not efficiently acting in the adaptation process of guardians given that their child's chronic disability is severe disability accompanying epilepsy. According to the result of such comparison, family resilience of the groups with a child who had cerebral palsy accompanying epilepsy was rather low but such difference was very small between the two groups. Overall, the groups with a child with cerebral palsy accompanying cerebral palsy were externally attributed. The small difference between the groups with a child with cerebral palsy accompanying epilepsy and the groups with a child with cerebral palsy not accompanying epilepsy suggests that regarding family resilience, the groups with a child with cerebral palsy accompanying epilepsy have potential family qualifications and have a duty to actively make family approach, and have ability to overcome hardships. Therefore, in the field of special education, family resilience should be improved and guardians should be more internally attributed to their child's disability and the need to support families for positive adaptation is required.

Based on the discussion and conclusion, this study proposes as follows for follow-up research on guardians with a child with cerebral palsy accompanying epileptic disability and the research on family support in the field of special education.

First, the scale of the test on attribution disposition and family resilience used in the present study was modified and complemented by the researchers from the scale on ordinary people. For certainty, the scale was used after reliability verification was made through profound preliminary research on guardians with a child with cerebral palsy accompanying epileptic disability but development of a more objective and general scale is needed in sufficient consideration of their special circumstances.

Second, more profound analysis of attribution disposition and family resilience of guardians with a child with cerebral palsy accompanying epileptic disability are necessary. In other words, examination on more specific and profound attribution disposition and family resilience characteristics are necessary by analyzing correlation among the sub-variables among the factors of this study's tool.

Third, at this point of time when demand on family support is becoming strong in the field of special education, follow-up research to support families with a child with cerebral palsy accompanying epilepsy through development and application of programs aimed at strengthening such families' attribution disposition and family resilience is necessary.

\section{References}

Austin, J. K., McDermott, N. (1988). Parental Attitude and coping Behaviors in families of children with Epilepsy. Journal of Neuroscience Nursing, 20(3), 174-179.

Bronfenbrenner, U. (1981). Die Oekologie der menschlichen Entwicklung. Stuttgart.

Cook, D., \& Ferritor, D. (1985). The family: A potential resource in the provision of rehabilitation services. Journal of Applied Rehabilitation Counseling, 16(2), pp.52-53.

Ellis, N., Upton, D., \& Thompson, R. (2000). Epilepsy and the Family: a review of current literature. Seizure. 9, 2230

Ferrari. M., Matthsews, W., \& Barabas, G. (1983). The family and the child with epilepsy. Family Process. 22, pp.53-59.

Hawley, D. R. (2000). Clinical Implication of Family Resilience. The American Journal of Family Therapy.

Hawley, D. R., \& Dehaan, L. (1996). Toward a definition of family resilience: Integrating life-span and family perspectives. Journal of Family Processes. 
Hoare, P. and Kerley, S. (1991). Psychosocial adjustment of children with chronic epilepsy and their families. Developmen Medicine \& Child Neurology, 33, pp.201-215

Jang, Y. M. (2002). The Effect on Adaptation of Mothers of Children with Cerebral Palsy from Social Support (Master' s thesis). Kyunggi University, Kyunggido, South of Korea.

Jeon, H. S. (2000). A Study on the Characteristics and Copying Strategies of Seizures Children with Cerebral Palsy. Korean Journal of Physical, Multiple, \& Health Disabilities, 35, 135-159.

Jun, J. S. (2001). A study on the Seizure Characteristics of Students with Cerebral Palsy (Master' s thesis). Daegu University, Daegu, South of Korea.

Jun, J. S. (2011). The Study on the Relationship between Attribution and Family Resilience in Family Adults of Children with Seizure Cerebral Palsy (Doctoral thesis). Daegu University, Daegu, South of Korea.

Kelley, S., \& Lambert, S. (1992). Family support in rehabilitation: A eview of research 1980-1990. Rehabilitation Counseling Bulletin, 36, pp. 98-119.

Kim, B. Y. (2000). FamilyFunctioningofFamilieswithEpileptic(Master' sthesis).Ewa Women University, Seoul, South of Korea.

Kim, J. Y. (2007). The Effect of a Social Support Intervention on Uncertainty, Coping, and Quality of Life in Mothers an Epileptic Child (Master' s thesis). Kungbuk University, Daegu, South of Korea.

Kim, M.O (2000). A study on social competence of children and adaptation of family of children with disabilities : focusing on the effects of family resilience (Doctoral thesis). Ewa Women University, Seoul, South of Korea.

Korea National Institute for Special Education (2000). SpecialEducationVision2020.

Lee, S. A. (2004). The Influence of The Familiy Resilience with the Fanily of Chronic illness child of Family Adaptaion(Doctoral thesis). Busan University, Busan, South of Korea.

Lustig (1996), Family Adaptation to a Young Adult with Mental Retardation, Journal of Rehabilitation. pp22-27

McCubbin, H., \& Patterson, J. M. (1983). The family stress process: The Double ABCX model of adjustment and adaptation. In H. McCubbin, M. Sussman \& J. M. Patterson(Eds). Social stress and the family: Advances in family: Advances in family stress theory and research. New York: Haworth Press.

Patterson, J. M. \& Garwick, A. W. (1994). Theoretical Link ages : Family meaning and sense of coherence. In H. McCubbin, E. Thomson, A. Thomson, \& J. Fromer(EDs), Sense of coherence and resiliency : Stress, coping, and health. Madison : Center for Excellence in Family Studies, University of Wisconsin.

Pianta, R. (1994). Prediction Behavior Problems in Children with Epilepsy: Child Factors, Disease Factors, Family Stress and Child-Mother Interaction. Child Development, 65, pp.1415-1428.

Power. P. W. (1988), Dell Orto, A. E., \& Gibbons, M. B., Family Interventions throughout Cronic Illness \& Disability, Springer Publishing Company: New York.

Sbarra, D. A. Rimm-Kaufman, S. E. \& Pianta, R. C. (2002). The behavioral and emotional correalates of epilepsy in adolescence a 7-year follow-up study. Epilepsy \& Behavior, 3, 358-367.

Seindenberg, M. (1992). Childhood epilepsy and the role of psychology. American Psychologist, 47, pp.1130-1133.

Sin, H. G. (2000). IntroductionofSpecialEducation.Seoul:Kyoyookbook.

Singer, G. H. S., \& Irvin, L. K. (1991). Supporting Families of persons with severs disabilities: Emerging findings, practices, and questions. In L. H. Meyer, C. A.

Singer, L. \& Farks, K. J. (1989). The Impact of Infant Disability on stress and Social Networks in Families with a Handicaped child. Family Relations, 33, pp.67-77.

Sutton, J. (1985). The need for family involvement in client rehabilitation. Journal of Applied Rehabilitation Counseling, 16(1), pp.42-45.

Walsh, F. (1996). The concept of Family Resilience3: Crisis and Challenge. Family Process, 35; 3, pp.261-281. 